\title{
Pengembangan Model Pembelajaran Terpadu Berbasis Budaya Lokal di SD Kota Metro
}

\author{
Tusriyanto \\ Institut Agama Islam Negeri Metro \\ Jl Ki Hajar Dewantara iring Mulyo Kota Metro Lampung \\ Email: tusriyanto@metrouniv.ac.id
}

Received: Jan 18, 2020

Revised: March 4, 2020

Accepted: April 21, 2020

\begin{abstract}
This research was focused on "Developing Integrated Learning Models Based on Local Culture in Metro City Elementary Schools". This research has only produced a draft of learning material about "Piil Pesenggiri" which will later be used as a module or teaching material in local culture-based learning in Metro City SD. In addition, based on the results of input and discussion in the FGD activities that learning media are needed in the form of benner standing which gives about the principle of "Pesenggiri Piil" so that it can be read by both teachers and students. Furthermore, learning plans will also be made from the lesson plans to the assessment of integrated learning based on Lampung's local culture. Local culture-based learning is needed as an effort to maintain the regional culture of each province including Lampung province.
\end{abstract}

Keywords: integrated larning, local culture, piil pesenggiri, elementary school

\begin{abstract}
Abstrak
Penelitian ini di fokuskan pada "Pengembangan Model Pembelajaran Terpadu Berbasis Budaya Lokal di SD Kota Metro". Penelitian ini baru menghasilkan draf materi pembelajaran tentang "Piil Pesenggiri" yang nantinya akan dijadikan sebagai modul atau bahan ajar dalam pembelajaran berbasis budaya lokal di SD Kota Metro. Selain itu berdasarkan hasil masukan dan pembahasan dalam kegiatan FGD bahwasanya dibutuhkan media pembelajaran berupa benner berdiri yang berikan tentang prinsip "Piil Pesenggiri" agar dapat dibaca oleh guru maupun siswa. Selanjutnya nanti juga akan dibuat rancangan pembelajaran dari RPP sampai dengan assesment pembelajaran terpadu berbasis budaya lokal Lampung. Pembelajaran berbasis budaya lokal sangat diperlukan sebagai upaya untuk mempertahankan kebudayaan daerah masing-masing propinsi termasuk propinsi Lampung.
\end{abstract}

Kata Kunci: Pemberlajaran Terpadu, Budaya Lokal, Piil Pesenggiri, SD 


\section{Pendahuluan}

Menurut Alexon dalam bukunya yang berjudul "Pembelajaran Terpadu Berbasis Budaya ada dua hal penting berkenaan dengan tantangan dan permasalahan yang dihadapi dunia pendidikan di Indonesia saat ini. Pertama, tantangan yang dihadapi lembaga pendidikan dasar di era globalisasi. Kedua, sistem pendidikan di sekolah yang cenderung parsial telah menjadikan manusia-manusia Indonesia kurang mengapresiasi budayanya. ${ }^{1}$ Sekolah sebagai bagian sistem pendidikan, dengan semua komponen yang terlibat di dalamnya, seolah mempunyai budaya sendiri yang berbeda dari budaya yang selama ini ada dan berlaku di lingkungan komunitas siswa. Mata pelajaran dan proses pembelajaran di sekolah juga memperkenalkan budaya lain yang berbeda dengan budaya komunitasnya.

Nilai-nilai luhur budaya yang dimiliki kelompok masyarakat di Indonesia merupakan potensi yang tak ternilai harganya untuk pembangunan dan kemajuan bangsa Indonesia. Masyarakat Indonesia merupakan masyarakat yang majemuk baik dari segi budaya, agama, maupun bahasa yang memiliki nilai-nilai luhur sebagai local wisdom-nya. Setiap suku bangsa Indonesia yang bhinneka itu memiliki kebudayaan sendiri, memiliki nilai-nilai budaya luhur sendiri, dan memiliki keunggulan lokal atau memiliki kearifan lokal (local knowladge, local wisdom) sendiri.

Menurut Alwasilah inilah yang melahirkan pendidikan bermakna deliberatif, yaitu "Setiap masyarakat berusaha mentransmisikan gagasan fundamental yang berkenaan dengan hakikat dunia, pengetahuan, dan nilai-nilai ". Kesadaran akan hal itu penting untuk dilakukan mengingat praktik pendidikan kita selama ini terlalu berorientasi ke Barat dan melupakan nilai-nilai keunggulan

${ }^{1}$ Alexon, Pembelajaran Terpadu Berbasis Budaya, (Bengkulu: Unit FKIP UNIB Press, 2010), h. 1 yang ada di Bumi Nusantara ini. ${ }^{2}$ Seperti dikemukakan Kartadinata (dalam Pengantar Buku Etnopedagogi karangan Alwasilah dkk) bahwa "Diantara kita selama ini silau dengan sistem pendidikan Barat sehingga buta terhadap keunggulan lokal yang lama terpendam dalam bumi kebudayaan Indonesia... dan UPI merespon dengan menggagas etnopedagogi". "Etnopedagogi adalah praktik pendidikan berbasis kearifan local. Kearifan lokal adalah proses bagaimana pengetahuan dihasilkan, disimpan, diterapkan, dan diwariskan". ${ }^{3}$ Oleh karena itu, perlu digagas dan dirumuskan model pendidikan karakter berbasis kearifan budaya lokal bagi masyarakat Indonesia yang majemuk secara budaya ini.

\section{Hasil Penelitian yang dilakukan} oleh Purwati Anggraini menunjukkan bahwa "Bahan ajar Bahasa Indonesia yang mengandung kearifan lokal tidak hanya membekali siswa dengan pengetahuan yang luas, tapi karakter yang kuat juga. Metode penelitian kualitatif digunakan untuk tujuan penelitian saat ini. Setelah menganalisa isi dari tujuh buku pelajaran Bahasa Indonesia untuk kelas 10 SMA, ada beberapa kearifan lokal disadap. Namun, beberapa teks yang tunduk pada perubahan, digantikan oleh berbagai teks yang berasal dari sejumlah daerah di seluruh Indonesia. Teks-teks dimaksudkan terkandung kearifan lokal yang lebih dan memberikan kontribusi untuk siswa pengetahuan diperluas tentang keberagaman di Indonesia. ${ }^{4}$

Penelitian lainnya dari Ghana, meneliti bagaimana pengetahuan budaya Adat memberikan informasi tentang pendidikan dan sosialisasi kepada pemuda dan menyarankan cara-cara untuk memikirkan kembali sekolah dan pendidikan dalam konteks Afrika. Di antara ajaran peribahasa Adat disorot pengetahuan

${ }^{2}$ Proceedings of The 4th International Conference on Teacher Education; Join Conference UPI E UPSIBandung, Indonesia, 8-10 November 2010

3 Ibid.

4 Journal of Education and Practice www.iiste.org ISSN 2222-1735 (Paper) ISSN 2222-288X (Online) Vol.6, No.33, 2015 
tentang diri dan masyarakat, pengembangan diri dan karakter, pentingnya disiplin sosial dan tanggung jawab sosial kolektif. Diskusi juga membahas tantangan mengintegrasikan pengetahuan budaya lokal sebagai bagian dari pendidikan formal pelajar muda. ${ }^{5}$

Selanjutnya penelitian dari Phaedra Mohammed and Permanand Moha menjelaskan rincian studi eksplorasi dan studi eksperimental dilakukan dengan menggunakan budaya berorientasi permainan pendidikan yang dibangun sesuai dengan rekomendasi untuk sistem pembelajaran enculturated. Hasil dan temuan dari kedua studi diuraikan, dan bukti yang disajikan dalam mendukung kelangsungan hidup dan kegunaan dari inklusivitas budaya di permainan berbasis lingkungan belajar pendidikan. ${ }^{6}$

Penelitian ini memberikan analisis global dan sintesis muncul etika masalah, situasi, dan pertanyaan yang dihadapi pendidik menggunakan teknologi digital. Para penulis menawarkan kerangka konseptual berpusat pada Konteks Etis Continuum (ECC) yang mengintegrasikan bagaimana masyarakat, budaya, nilai-nilai, dan teknologi yang dirasakan oleh orang-orang dan membuat pilihan etis yang menganggap potensi bahaya, manfaat atau baik untuk individu dan kelompok. Ringkasan area isu etika yang muncul dibahas dan rekomendasi yang ditawarkan untuk mengadaptasi praktik terbaik global dan pelajaran di tingkat lokal di Catalonia. Para penulis menyimpulkan bahwa jangkauan dan kompleksitas masalah etika potensial relevan dengan penggunaan teknologi digital akan berkembang di masa depan. Pengembangan dariKode komprehensif Etik Penggunaan Digital Technologies sangat dianjurkan di semua masyarakat sektor di Catalonia. Penelitian ini dan rekomendasi

5 George J. Sefa Die, Jurnal "Canadian and International Education", vol. 40 issue 1 tanggal 1 Juni 2011 Articles 3

6 Phaedra Mohammed and Permanand Mohan, Caribbean Teaching Scholar Vol. 1, No. 1, April 2011, 21-33 lainnya juga dapat diterapkan dalam konteks lokal dan nasional lainnya.?

Peran sekolah sebagai bagian terpenting dalam mempertahankan budaya bangsa sudah kalah dengan perkembangan teknologi yang sangat cepat mengubah budaya masyakat. Sekolah-sekolah di Indonesia yang mendasarakan kebangsaan atau kebudayaan tidak mampu mempertahankan prinsip dasar pendirian sekolah itu sendiri. Prinsip-prinsip dasar dimana sekolah didirikan juga tergerus oleh tuntutan modernitas.

Zamroni menjelaskan bahwa perkembangan dunia pendidikan membawa dua problem utama. Pertama, terjadi proses industrialisasi sekolah yang memiliki watak liberalistis dan kapitalistis. Akibatnya, jiwa pendidikan tergusur oleh perhitunganperhitungan dan kepentingan ekonomi. Kedua, sekolah telah menghasilkan lulusan yang tercabut dari akar budaya. Karena sekolah menawarkan budaya urban, maka lulusan sekolah berbudaya urban tidak betah tinggal di desa, maka berbondong para generasi muda terdidik bermigrasi ke kota-kota. Pernyataan indah "Think globally, act locally (berpikir global, bertindak secara lokal)", hanya jadi mitos. Realitas adalah "think globally, act globally as well (berpikir secara global, serta bertindak secra global)" ${ }^{\prime \prime}$. Melihat relaitas ini dirasa sangat penting untuk menerapkan pembelajaran terpadu berbasis budaya, khususnya di Sekolah Dasar.

Berdasarkan dari latar belakang tersebut di atas, maka diperlukan suatu upaya untuk tetap menjaga dan melestarikan budaya nasional sebagai salah satu unsur pemersatu bangsa Indonesia sejak dini. Nilai-nilai yang

7 Olcott Jr. D., Carrera Farran, X., Gallardo Echenique, E. E., \& González Martínez, J. (2015). Ethics and Education in the Digital Age: Global Perspectives and Strategies for Local Transformation in Catalonia. RUSC. Universities and Knowledge Society Journal, 12(2). pp. 59-72. doi http://dx.doi.org/10.7238/rusc.v12i2.2455

${ }^{8}$ http://kiens-edu.blogspot.co.id/2014/09/ pendidikan-berbasis-budaya-lokal.html diakses tanggal 28 Januari 2017 
selama ini mencirikan bangsa Indonesia adalah hidup rukun, saling menghargai, pekerja keras, gotong-royong, ramah tamah, dan lain-lain harus tetap dipelihara dan harus ditanamkan sejak anak berada di bangku Sekolah Dasar. Contohnya mengajarkan bersahabat dengan teman sekelas, bekerja dalam kelompok yang beragam latar belakang agama dan suku bangsa dan seterusnya. Secara keseluruhan jumlah Sekolah Dasar yang ada di Kota Metro lebih kurang 66 Sekolah Dasar baik Negeri Maupun Swasta. ${ }^{9}$ Berdasarkan hasil wawancara di beberapa sekolah bahwasanya pembelajaran berbasis budaya belum diberikan secara optimal, arah pembelajaran hanya sekedar untuk menyampaikan materi dan siswa hanya memperoleh pengetahuan pada aspek kognitif saja.

Pada penelitian ini di fokuskan pada "Pengembangan Model Pembelajaran Terpadu Berbasis Budaya Lokal di SD Kota Metro" , hasilnya diharapkan siswa tidak lagi terasing dengan budayannya dan menjadi pribadi yang dapat menjaga nilai-nilai budaya daerahnya (budaya lokal). Hal ini sejalan dengan visi Kota Metro 2015-2020, yaitu “Percepatan Kota Metro sebagai Kota Pendidikan dan Wisata Keluarga melalui Pembangunan Ekonomi Kerakyatan yang berkualitas, berkarakter dan berwawasan lingkungan dengan melibatkan partisipasi publik". ${ }^{10}$ Selain dalam kunjungannya di Kota Metro beberapa waktu lalu juga menyampaikan “"Di pendidikan dasar, yakni untuk SD, harus lebih banyak diperkuat dengan aktivitas pendidikan karakter daripada pengetahuan". ${ }^{11}$ Jadi sangatlah penting untuk mengembangkan Pembelajaran Terpadu Berbasis Budaya di SD, khususnya di SD yang berada di Kota Metro

\footnotetext{
${ }^{9}$ http://metromaju.blogspot.co.id/2012/10/datasd-di-kota-metro.html

10 Pairin dan Djohan, Metro Sebagai Kota Pendidikan dan Wisata Keluarga, visi misi yang disampaikan tanggal 29 Juli 2015.

${ }^{11}$ http://www.jurnalguru.net/2016/11/mendikbudkota-metro-sebagai-kota.html diakses tanggal 03 April 2017
}

sebagai upaya untuk menanamkan nilai-nilai kebangsaan.

Nilai-nilai budaya yang dimiliki suatu suku bangsa akan menjadi standar normatif untuk berperilaku, dalam hal ini fokus kajian penelitian pada budaya Lampung. Pada prinsipnya, Lampung memiliki falsafah hidup yang dikenal dengan lima aspek yaitu pi'il pesenggiri, bejuluk beadok, nemui nyimah, nengah nyampur dan sakai sembayan. Pi'il pesenggiri adalah rasa punya harga diri. Kemudian bejuluk-beadok (gelar adat) merupakan identitas utama yang melekat pada pribadi. Bejuluk-beadok merupakan asas identitas dan sebagai sumber motivasi bagi anggota masyarakat Lampung untuk dapat menempatkan hak dan kewajibannya, kata dan perbuatannya dalam setiap perilaku dan karyanya. Falsafah yang ketiga yaitu nemui-nyimah merupakan ungkapan asas kekeluargaan untuk menciptakan suatu sikap keakraban dan kerukunan serta silaturahmi. Bentuk konkrit nemui nyimah dalam konteks kehidupan masyarakat dewasa ini lebih tepat diterjemahkan sebagai sikap kepedulian sosial dan rasa setiakawan. ${ }^{12}$

Suatu keluarga yang memiliki kepedulian terhadap nilai-nilai kemanusiaan, tentunya berpandangan luas ke depan dengan motivasi kerja keras, jujur dan tidak merugikan orang lain. Falsafah yang keempat yaitu nengah nyampur merupakan sikap suka bergaul suka bersahabat dan toleran antar sesama. Nengah-nyampur menggambarkan bahwa anggota masyarakat Lampung mengutamakan rasa kekeluargaan dan didukung dengan sikap suka bergaul dan bersahabat dengan siapa saja, tidak membedakan suku, agama, tingkatan, asal usul dan golongan. Falsafah yang terakhir yaitu sakai sembayan bermakna tolong menolong dan gotong royong, artinya memahami makna kebersamaan atau guyub.

12 Nita Fitria, "Pola Asuh Orang Tua Dalam Mendidik Anak Usia Pra Sekolah Ditinjau Dari Aspek Budaya Lampung", dalam Jurnal Fokus Konseling Volume 2 No. 2, Agustus 2016, h. 99-115 
Sakai-sambayan pada hakekatnya adalah menunjukkan rasa partisipasi serta solidaritas yang tinggi terhadap berbagai kegiatan pribadi dan sosial kemasyarakatan pada umumnya. Sebagai masyarakat Lampung akan merasa kurang terpandang bila ia tidak mampu berpartisipasi dalam suatu kegiatan kemasyarakatan. Perilaku ini menggambarkan sikap toleransi kebersamaan, sehingga seseorang akan memberikan apa saja secara suka rela apabila pemberian itu memiliki nilai manfaat bagi orang atau anggota masyarakat lain yang membutuhkan.

Tata nilai budaya masyarakat Lampung sebagaimana diuraikan di atas, pada dasarnya merupakan kebutuhan hidup dasar bagi seluruh anggota masyarakat setempat agar survive secara wajar dalam membina kehidupan dan penghidupannya yang tercermin dalam tata kelakuan sehari-hari, baik secara pribadi ataupun bersama dengan anggota kelompok masyarakat maupun bermasyarakat secara luas.

Dalam membina kehidupan dan penghidupan yang wajar diperlukan ramburambu normatif sebagai pedoman untuk berperilaku. Rambu-rambu dan pedoman itu berwujud ketentuan-ketentuan, yang berisi larangan (cepalo) dan keharusan (adat) untuk diamalkan oleh setiap anggota masyarakat pendukungnya. Sudah menjadi kenyataan bahwa pedoman hidup tersebut merupakan sarana untuk pembentukkan sikap dan perilaku. Masyarakat Lampung juga mempunyai strata (tingkatan) kehidupan, baik berdasarkan status genealogis (keturunan, Umur), maupun status sosial dalam adat (penyimbang buwai, tiyuh, dan suku). Dalam sistem strata kehidupan masyarakat adat sehari-hari terjadi interaksi antara anggota kelompok intern satu keturunan adat dan antar kelompok masyarakat yang berbeda keturunan adatnya.

\section{Metode Penelitian}

Penelitian ini menggunakan metode research development dimana dari penelitian ini akan muncul strategi baru dalam pengembangan model pembelajaran terpadu berbasis budaya di SD Kota Metro. Sugiono ${ }^{12}$ menjelaskan bahwa, penelitian pengembangan adalah metode penelitian yang digunakan untuk menghasilkan produk tertentu, dan menguji keefektifan produk tersebut.

Berikut gambar Langkah-langkah penelitian ini mengacu pada langkah penelitian dari Sugiono, sebagai berikut: ${ }^{13}$

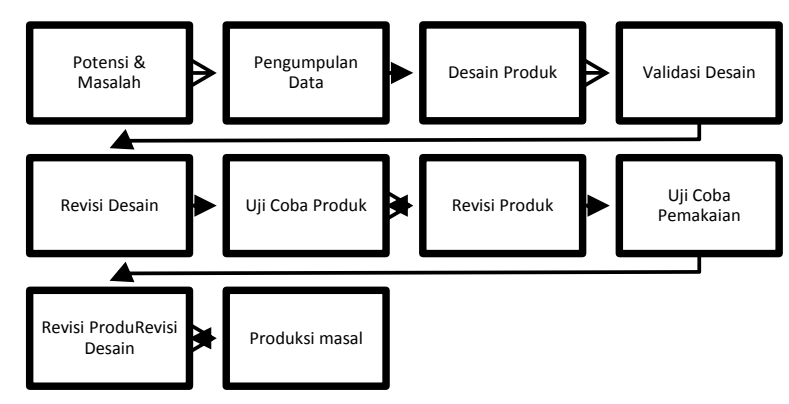

Bagan 1. Langkah-Langkah Penelitian

\section{Hasil Penelitian dan Pembahasan}

Berdasarkan hasil angket diperoleh bahwasanya pemahaman guru tentang budaya dan pembelajaran berbasis budaya hanya $71 \%$ diperoleh dari guru kelas 1-6. Berdasarkan hasil angket diperoleh bahwasanya pemahaman guru tentang PIIL Pesenggiri sebesar 51\% yang memahaminya diperoleh dari guru kelas 1-6. Hal ini menunjukkan bahwasanya pemahaman guru terhadap pembelajaran berbasis budaya lokal masih memerlukan pembinaan serta pemahaman guru tentang materi kearifan lokal lampung berkaitan dengan prinsip hidup "Piil Pesenggiri" masih harus diberikan melalui pengembangan materi untuk memperluas pengetahuan guru sebelum melakukan kegiatan pembelajaran.

Seorang guru harus memiliki kamampuan untuk mewujudkan tujuan pendidikan nasional Persyaratan ini lebih mengarah pada tugas guru sebagai pengajar. 
Guru harus mampu mengutarakan peserta didiknya mencapai tujuan tujuan pembelajaran yang telah ditetapkan. Dengan berpegang pada herarki tujuan pendidikan, tercapainya tujuan pembelajaran mengandung arti tercapainya tujuan kurikuler. Tercapainya tujuan kurikuler mengandung arti tercapainya tujuan lembaga dan tercapainya tujuan lembaga memiliki makna tercapainya tujuan pendidikan nasional. ${ }^{14}$ Kompetensi guru sebagaimana dimaksud dalam Pasal 8 meliputi kompetensi pedagogik, kompetensi kepribadian, kompetensi sosial, dan kompetensi profesional yang diperoleh melalui pendidikan profesi. ${ }^{15}$ Kompetensi paedagogik merupakan "kemampuan mengelola pembelajaran peserta didik". Kompetensi ini dapat dilihat dari kemampuan merencanakan program belajar mengajar, kemampuan melaksanakan interaksi atau mengelola proses belajar mengajar, dan kemampuan melakukan penilaian. Misalnya sebelum mengajar guru membuat rencana pelaksanaan pembelajaran terlebih dahulu yang didalamnya mencakup bagagaimana proses belajar mengajar nantinya akan dilaksanakan sehingga guru tidak akan bingung dalam mengelola kelas dan memberikan penilaian.

Kemampuan Pribadi. Guru sebagai tenaga pendidik yang tugas utamanya mengajar, memiliki karakteristik kepribadian yang sangat berpengaruh terhadap keberhasilan pengembangan sumber daya manusia. Kepribadian yang mantap dari sosok seorang guru akan memberikan teladan yang baik terhadap anak didik maupun masyarakatnya, sehingga guru akan tampil sebagai sosok yang patut "digugu" (ditaati nasehat/ucapan/ perintahnya) dan "ditiru" (di contoh sikap dan perilakunya). Kepribadian guru merupakan faktor terpenting bagi keberhasilan belajar anak didik. Misalnya dalam bertutur kata atau

14 UU No. 14 Tahun 2005 tentang Guru dan Dosen BAB IV Pasal 8 "Kualifikasi, Kompetensi dan Sertifikasi".

15 UU No. 14 Tahun 2005 tentang Guru dan Dosen BAB IV Pasal 10 dalam bertingkah laku harus sopan sehingga guru tersebut mampu menjadi panutan bagi peserta didik.

Kemampuan Sosial. Guru yang efektif adalah guru yang mampu membawa siswanya dengan berhasil mencapai tujuan pengajaran. Mengajar di depan kelas merupakan perwujudan interaksi dalam proses komunikasi. Menurut Undang-undang Guru dan Dosen kompetensi sosial adalah "kemampuan guru untuk berkomunikasi dan berinteraksi secara efektif dan efisien dengan peserta didik, sesama guru, orangtua/ wali peserta didik, dan masyarakat sekitar". Misalnya pada saat guru menjelaskan materi didepan kelas, ada interaksi dengan siswa

Kompetensi profesional adalah "kemampuan penguasaan materi pelajaran secara luas dan mendalam".Kompetensi profesional meliputi kepakaran atau keahlian dalam bidangnya yaitu penguasaan bahan yang harus diajarkannya beserta metodenya, rasa tanggung jawab akan tugasnya dan rasa kebersamaan dengan sejawat guru lainnya. Misalnya Guru menguasai secara mendalam bahan/mata pelajaran yang diajarkannya serta mengajarkannya kepada siswa. Bagi guru, hal ini merupakan dua hal yang tidak dapat dipisahkan. Guru bertanggungjawab memantau hasil belajar siswa melalui berbagai teknik evaluasi, mulai cara pengamatan dalam perilaku siswa sampai tes hasil belajar. ${ }^{16}$

Selanjutnya, hasil penelitian yang dilakukan oleh Wahira menyimpulkan pembelajaran seni tari khususnya pada penanaman kearifan lokal masih memerlukan penanganan yang lebih baik agar sasaran semakin mudah dicapai pada akhirnya, pendidikan nilai budaya, dan guru sekolah dasar yang tidak berlatar belakang bakat seni agar berminat untuk mengikuti pelatihan pembelajaran seni tari berbasis saintifik, yang berhubungan dengan strategi manajemen

16 UU No. 14 Tahun 2005 tentang Guru dan Dosen BAB IV Pasal 10 ayat 1 
pendidikan nilai budaya daerah setempat yang melibatkan seluruh pendidik yang dicantumkan dalam kurikulum 2013. Implementasi pendidikan seni tari disekolah dasar belum efektif, sistem kerja yang menggunakan manajemen partisipasi belum optimal, karena upaya motivasi sekolah terhadap para pendidik masih rendah. ${ }^{17}$

Perubahan budaya yang diakibatkan oleh media massa mencakup hampir semua sisi kehidupan manusia. Ini terjadi, disebabkan antaranya kekuatan jangkauan media, kemudahan memperoleh akses dan semakin banyak masyarakat yang mampu mengakses informasi karena penurunan biaya media massa. Perubahan budaya mengarah pada budaya massa atau budaya populer, dimasa hampir tidak ada lagi perbedaan antara budaya elit dan budaya rakyat. Perkembangan media massa juga menciptakan dominasi budaya, dominasi dapat terjadi karena negaranegara kuat dengan perusahaan transnasional, menguasai hampir seluruh penyiaran satelit, menciptakan sekaligus "menual" budaya popupler sebagai komoditas ekonomi dan sosial budaya, kepada negara-negara berkembang termasuk Indonesia. ${ }^{18}$

Berdasarkan hasil observasi dan wawancara dengan guru serta kepala sekolah dibeberapa SD yang berada di Kota Metro baik yang berstatus negeri maupun swasta bahwasannya belum dikembangkannya model pembelajaran terpadu berbasis budaya lokal terutama kearifan lokal lampung berkaitan dengan prinsip hidup "Piil Pesenggiri" Kenyataaan tersebut mengakibatkan generasi penerus bangsa cenderung kesulitan untuk menyerap nilai-nilai budaya menjadi kearifan lokal sebagai sumber daya untuk memelihara dan meningkatkan martabat dan kesejahtaraan

17 Wahira, “Kebutuhan Pelatihan Manajemen Pembelajaran Seni Tari Berbasis Pendekatan Saintifik Pada Guru Sekolah Dasar" dalam Catharsis: Journal of Arts Education 3 (2) 214

18 Dominikus Tulasi, “Terpaan Media Massa dan Turbulensi Budaya Lokal" dalam Jurnal Humaniora Vol. 3 No. 1 April 2012: 135-144 bangsa. Generasi sekarang semakin kehilangan kemampuan dan kreativitas dalam memahami prinsip kearifan lokal.

Hal ini disebabkan oleh adanya penyimpangan kepentingan para elit masyarakat dan pemerintah yang cenderung lebih memihak kepada kepentingan pribadi dan golongan dari pada kepentingan umum. Kepentingan subyektivitas kearifan lokal ini selalu dimanfaatkan untuk mendapatkan status kekuasaan dan menimbun harta dunia. Para elit ini biasanya melakukan pencitraan ideal kearifan lokal di hadapan publik seolah membawa misi kebaikan bersama. Akan tetapi sebagaimana diketahui bahwa pada realisasinya justeru nilai-nilai luhur yang terkandung di dalamnya tidak lebih hanya sekedar alat untuk memperoleh dan mempertahan kekuasaan. Pada gilirannya, masyarakat luas yang struktur dan hubungan sosial budayanya masih bersifat obyektif sederhana makin tersesat meneladani sikap dan perilaku elit mereka, juga makin lelah menanti janji masa depan, sehingga akhirnya mereka pesimis, putus asa dan kehilangan kepercayaan.

Namun demikian, meski masyarakat cemas bahkan ragu terhadap kemungkinan nilai-nilai luhur budaya itu dapat menjadi model kearifan lokal, akan tetapi upaya menggali kearifan lokal tetap niscaya dilakukan. Masyarakat adat daerah memiliki kewajiban untuk kembali kepada jati diri mereka melalui penggalian dan pemaknaan nilai-nilai luhur budaya yang ada sebagai sumber daya kearifan lokal. Upaya ini perlu dilakukan untuk menguak makna substantif kearifan lokal, di mana masyarakat harus membuka kesadaran, kejujuran dan sejumlah nilai budaya luhur untuk sosialisasikan dan dikembangkan menjadi prinsip hidup yang bermartabat. Misalnya nilai budaya "NemuiNyimah" sebagai kehalusan budi diformulasi sebagai keramahtamahan yang tulus dalam pergaulan hidup. Piil Pesenggiri sebagai prinsip 
hidup niscaya terhormat dan memiliki harga diri diletakkan dalam upaya pengembangan prestasi, kreativitas dan peranan yang bermanfaat bagi masyarakat, demikian juga dengan makna-makna kearifan lokal nilai-nilai budaya lainnya. Kemudian pada gilirannya, nilai-nilai budaya ini harus disebarluaskan dan dibumikan ke dalam seluruh kehidupan masyarakat agar dapat menjadi jati diri masyarakat daerah. Keberadaan Piil Pesenggiri merupakan aset (modal, kekayaan) budaya bangsa yang perlu dilindungi dan dilestarikan untuk meningkatkan kesadaran jatidiri bangsa untuk diteruskan kepada generasi berikutnya dalam keadaan baik.

Dalam proses kompromi budaya, kearifan lokal bukan hanya berfungsi menjadi filter ketika terjadi benturan antara budaya lokal dengan tuntutan perubahan. Lebih jauh, nilai-nilai budaya lokal berbicara pada tataran penawaran terhadap sumberdaya nilai-nilai kearifan lokal sebagai pedoman moral dalam penyelesaian masalah ketika sebuah kebudayaan berhadapan dengan pertumbuhan antagonis berbagai kepentingan hidup.

Sebagaimana contoh pada kehidupan masyarakat lokal, proses kompromi budaya selalu memperhatikan elemen-elemen budaya lokal ketika berhadapan dengan budaya-budaya yang baru. Elemen-elemen itu dipertimbangkan, dipilah dan dipilih mana yang relevan dan mana pula yang bertentangan. Hasilnya selalu menunjukkan wajah sebuah kompromi yang elegan, setiap elemen mendapatkan tempat dan muncul dalam bentuknya yang baru sebagai sebuah kesatuan yang harmonis.

Tentu saja terbentuknya kesatuan yang harmonis itu tidak lepas dari hasil kompromi keadilan yang menyentuh kepentingan berbagai pihak. Kepentingan-kepentingan yang dimaksud sangat luas cakupannya, tetapi secara garis besar meliputi berbagai permasalahan yang berhubungan dengan kelangsungan hidup manusia, terutama yang bersifat primer dan praktis. Bagi pembuat kebijakan harus mampu memilah dan memilih proses kompromi yang menguntungkan semua pihak, kemudian menyikapi, menata, menindaklanjuti arah perubahan kepetingankepentingan itu agar tetap dalam prinsip kebersarnaan. Kebudayaan sebagai lumbung nilai-nilai budaya lokal bisa menjadi sebuah pedoman dalam upaya rnerangkai berbagai kepentingan yang ada secara harmonis, tanpa ada pihak yang dikorbankan.

Di Sekolah Dasar juga tidak terlepas dari keragaman budaya, etnis dan kepentingan, baik dari segi pembelajaran, staf sebagai pendukung kegiatan proses belajar mengajar, siswa, guru, dan tenaga administrasi lainnya. Keadaan ini seringkali menimbulkan perselisihan dan gagal paham antara pengelola pendidikan, lantaran terjadi pengingkaran terhadap peraturan sekolah, etika siswa, standar nilai (ganda), kebijakan sepihak, dan kekurangpercayaan terhadap pimpinan.

Idealnya budaya sekolah semestinya terkondisi stabilitas atmosfer saling memahami dan mendukung kinerja lainnya, yaitu pegawai administrasi, petugas keamanan dan kebersihan; dalam interaksi dan komunikasi diantara komponen itu tentu disertai sikap santun. Siswa yang baik dapat menempatkan diri sebagai pribadi yang santun dan ramah. Hal ini akan sangat membantu dalam mewujudkan keharmonisan hidup bermasyarakat hususnya di Sekolah Dasar.

Oleh karena itu direkomendasikan bahwa nilai-nilai kearifan lokal Lampung, khususnya pandangan hidup PIIL PESENGIRI dapat diadopsi sebagai pedoman moral spiritual dalam beraktivitas sekolah. Tujuannya adalah menamamkan prinsip hidup terhormat dan memiliki harga diri diletakkan dalam upaya pengembangan prestasi, kreativitas dan peranan yang bermanfaat bagi masyarakat sekolah. Kemudian pada gilirannya, nilainilai budaya ini harus dibumikan sebagai jati 
diri ke dalam seluruh jaringan kehidupan Sekolah Dasar.

Sedangkan masalah adalah penyimpangan antara yang diharapkan dengan yang terjadi. Masalah yang terdapat dalam penelitian ini adalah masih kurang kesadaran dan pengetahuan guru SD tentang model pembelajaran terpadu berbasis budaya lokal di Sekolah Dasar. Dengan model penelitian pengembangan dapat ditemukan strategi pengembangan model pembelajaran, sehingga dapat meningkatkan kompetensi dan daya saing lulusan.

\section{Berdasarkan hasil wawancara di} beberapa sekolah dengan beberapa kepala sekolah, guru dan siswa bahwasanya pembelajaran berbasis budaya terutama yang berkaitan dengan budaya lokal belum diberikan secara optimal, arah pembelajaran hanya sekedar untuk menyampaikan materi dan siswa hanya memperoleh pengetahuan pada aspek kognitif saja.

Praktik pembelajaran yang berkaiatan dengan budaya lokal yang diimplementasikan di SD Muhammadiyah Metro diberikan waktu dihari-hari tertentu, di hari Rabu Full tema kegiatan yang dilakukan antara lain praktik kegiatan tari daerah (tari sembah, tari cangget agung, tari melinting, tari bedana), pembuatan wayang dari kardus, rumah adat dan lainlain. Pada hari Jum'at kegiatan yang dilakukan adalah mempraktikkan berbagai permainan daerah, contohnya congklak, gobak sodor, lompat tali, dan lain-lain tujuannya untuk kebugaran anak.

Tujuan utama penerapan pembelaaran berbasis budaya lokal sebaiknya dititikberatkan pada pemahaman dan penghargaan peserta didik terhadap budayannya sendiri dan budaya orang lain, mencakup agama, berlandaskan semboyan "BHINNEKA TUNGGAL IKA" serta Pancasila. Untuk itu maka diperlukan adanya penataan ulang dan penguatan pendidikan IPS dengan memasukkan muatan materi keanekaragaman nilai budaya, ditambah penelitian sosiologis dan antropologis untuk pendidikan. ${ }^{19}$

Penelitian selanjutnya dari Umar M. Sadjim, dkk. Hasil penelitian menunjukkan bahwa pengembangan nilai-nilai kearifan lokal yang direvitalisasi, melalui: (a) konsesus bersama; (b) reinternalisasi dengan jalur informal, learning society dan formal; (c) nilai kearifan lokal terdiri dari nilai filosofi, pendidikan, sosial kemasyarakatan, ritual keagamaan dan nilai kebangsaan. ${ }^{20}$

Masyarakat Lampung memiliki kebudayaan lokal yang masih kental, dan berpotensi besar sebagai asas utama bagi terselenggarannya pendidikan yang ideal. Manajemen pendidikan yang berbasis pada buadaya lokal ini, dengan sendirinya, merupakan manifestasi dari pendidikan yang demokratis dan berbasis masyarakat (community-basededucation). Dengan menggunakan metode deskriptif dan pendekatan fenomenologis, dapat dipahami bahwa manajemen berbasis budaya Lampung ini adalah sebuah keniscayaan bagireformasi manajemen dalam dunia pendidikan, khususnya dikalangan masyarakat Lampung. Selain itu, ia juga memiliki landasan normatif sekaligus filosofis yang berakar dari nilai-nilai tradisi lokal, serta sebagai tuntutan aman yang semakin demokratis di negara yang menganut sistem demokrasi. ${ }^{21}$

Berdasarkan hasil analisis data skor setiap aspek tingkah laku prososial pada 15 siswa yang mendapatkan layanan bimbingan

${ }^{19}$ Tatang M. Amirin, “ Implementasi Pendekatan Pendidikan Multikultural Kontektual Berbasis Kearifan Lokal Di Indonesia" dalam Jurnal Pembangunan Pendidikan Fondasi dan Aplikasi. Fakultas Ilmu Pendidikan Universitas Negeri Yogyakarta. Vol. I, Nomor I Juni 2012.

20 Umar M. Sadim, dkk., "Revitaisasi NilaiNilai Bhinneka Tunggal Ika dan Kearifan Lokal Berbasis Leaning Society Pascakonflik Sosial di Ternate" dalam Jurnal Pembangunan Pendidikan: Fondasi dan Aplikasi P-ISSN: 2356-1807 e-ISSN: 2502-1648

${ }^{21}$ Nirva Diana, "Manajemen Pendidikan Berbasis Budaya Lokal Lampung (Analisis Eksploratif Mencari Basis Filosofis)" dalam Jurnal Analisis Vol. XII, Nomor 1 Juni 2012 
kelompok berbasis tata nilai budaya Lampung, tingkah laku prososial siswa mengalami peningkatan yang signifikan dimana skor keseluruhan sebelum mengikuti layanan mencapai 1929 kemudian skor setelah mengikuti layanan meningkat menjadi 2631. Maka ini berarti Ho ditolak dan Ha diterima yaitu model bimbingan kelompok berbasis tata nilai budaya Lampung efektif untuk meningkatkan tingkah laku prososial siswa. ${ }^{22}$

Produk yang dihasilkan dari penelitian ini adalah model pembelajaran terpadu berbasis budaya lokal yang berupa RPP berbasis budaya, media pembelajaran materi pembelajaran serta penilaian pembelajaran. Validasi desain merupakan proses kegiatan untuk menilai apaka rancangan produk, dalam ini merupakan model pembelajaran terpadu berbasis budaya lokal efektif atau tidak. Validasi produk akan dilakukan dengan cara menyusun desain pembelajaran secara bersama-sama antara peneliti sebagai nara sumber serta guru kelas yang dipilih untuk menetapkan model pembelajaran terpadu berbasis budaya lokal ini. Sehingga dapat diketahui kelemahan dan kelebihan dari model ini. Validasi ini akan dilakukan malalui forum diskusi sebelum dilakukan proses penelitian lanjutan.

Setelah dilakukan perbaikan desain produk melalui diskusi antara peneliti dengan guru-guru kelas di SD Muhammadiyah Metro, maka ditemukan kelemahan dan kelebihan. Perbaikan desain model akan dilakukan oleh peneliti sebelum proses penelitian dilanjutkan ke tahap berikutnya.

Berdasarkan hasil diskusi antara peneliti dan nara sumber bahwasanya diperlukan RPP pembelajaran berbasis budaya, pengembangan materi tentang "Piil Pesenggiri", media pembelajaran berbasis budaya lokal disertai

${ }^{22}$ Nita Fitria, "Bimbingan Kelompok Berbasis Tata Nilai Budaya Lampung Untuk Meningkatkan Tingkah Laku Prososial Siswa" dalam Jurnal Fokus Konseling, Vol. 1 No. 2 Agustus 2015, h. 162-171 lembar observasi untuk menilai kegiatan pembelajaran.

Dalam bidang sosial, uji coba produk yang dihasilkan dapat langsung di uji cobakan setelah melalui tahap validasi dan perbaikan desain. Uji coba dilakukan dengan simulasi terlebih dahulu kemudian di uji coba kepada kelompok yang terbatas. Uji coba dilakukan dengan mitra penelitian, yaitu Sekolah Dasar yang dipilih peneliti. Proses uji coba dilakukan kepada kelompok yang terbatas, yaitu akan dilakukan pada SD Muhammadiyah Kota Metro.

Kemudian Uji coba sebenarnya akan dilakukan melalui eksperimen untuk membandingkan efektifitas dan pencapaian model pembelajaran terpadu berbasis budaya ini. Eksperimen akan dilakukan dengan cara membandingkan keadaan sebelum dan sesudah (before-after) memakai model pembelajaran terpadu berbasis budaya lokal ini.

Revisi produk akan dilakukan setelah tahap uji coba produk. Untuk mengetahui tanggapan masyarakat dan efektifitas dalam penggunaan model pembelajaran terpadu berbasis budaya sebagai salah satu model pembelajaran yang diterapkan di SD Muhammadiyah Kota. Berdasarkan hasil dari wawancara dengan beberapa guru dan masyarakat pemerhati pendidikan bahwasanya model pembelajaran berbasis budaya harus terus dikembangkan untuk menggali lebih mendalam kearifan lokal lampung.

Setelah uji coba produk telah berhasil dilakukan dan produk telah direvisi kembali, maka tahap selanjutnya adalah uji coba pemakaian. Dalam keadaan nyata maka model ini dapat diterapkan. kekurangan dan kelebihan dalam pelaksanaan tetap harus dilaksanakan dalam tahap ini.

Berdasarkan hasil penelitian bahwasanya model pembelajaran berbasis budaya lokal memerlukan persiapan yang lebih ekstra dibandingkan dengan kegiatan pembelajaran yang lainnya. Untuk itu dukungan semua pihak 
untuk pengembangan model pembelajaran ini sangat dibutuhkan baik dari guru, siswa, pihak sekolah maupuan masyarakat.

Apabila dalam kondisi nyata dala penerapan model masih terdapat kelemahan dan kekurangan maka akan dilakukan revisi produk kembali. Meskipun kegiatan pembelajaran sudah dilakukan melalui kegiatan ini revisi masih terus dilakukan untuk mendapatkan hasil yang lebih baik

Pembuatan produk masal akan dilakuan apabila produk telah dinyatakan efektif dan layak untuk diproduksi masal. Yaitu diterapkan pada masyarakat yang lebih luas. Serta diperlukan kerjasama dari pihak-pihak yang terkait seperti pemerintah Kota Metro melalui dinas Pendidikan dan Kebudayaan. Untuk sementara produk terbatas pada SD Muhammadiyah Kota Metro terutama untuk pengembangan media pembelajaran untuk mengenalkan prinsip "piil pesenggiri" dibuat bener mulai dari pintu masuk sampai serta lokasi tertentu yang memungkinkan guru. Siswa, dan pihak sekolah untuk melihat dan membaca bener tersebut.

Produk Penelitian ini seharusnya mencakup perangkat pembelajaran terpadu berbasis budaya lokal di SD Muhammadiyah Kota Metro, yang meliputi:
a. Rencana Pelaksanaan Pembelajaran
b. Media Pembelajaran
c. Materi Pembelajaran
d. Assesment Pembelajaran
e. Keterlibatan Sekolah, Guru dan Siswa

Keterlibatan sekolah, guru dan siswa pada kegiatan penelitian mencakup halhal berikut ini: (1) implementasi model pembelajaran; (2) refleksi pembelajaran pada refleksi terbatas; dan refleksi pembelajaran pada refleksi meluas.

Penelitian ini baru menghasilkan draf materi pembelajaran tentang "Piil Pesenggiri" yang nantinya akan dijadikan sebagai modul atau bahan ajar dalam pembelajaran berbasis budaya lokal di SD Kota Metro.
Selain itu berdasarkan hasil masukan dan pembahasan dalam kegiatan FGD bahwasanya dibutuhkan media pembelajaran berupa benner berdiri yang berikan tentang prinsip "PIIL PESENGGIRI" agar dapat dibaca oleh guru maupun siswa. Selanjutnya nanti juga akan dibuat rancangan pembelajaran dari RPP sampai dengan assesment pembelajaran terpadu berbasis budaya lokal Lampung.

\section{Kesimpulan}

Berdasarkan hasil data dan analisis data penelitian dapat disimpulkan bahwasanya pemahaman guru tentang budaya dan pembelajaran berbasis budaya hanya $71 \%$ diperoleh dari guru kelas 1-6. Berdasarkan hasil angket diperoleh bahwasanya pemahaman guru tentang PIIL Pesenggiri sebesar 51\% yang memahaminya diperoleh dari guru kelas 1-6. Hal ini menunjukkan bahwasanya pemahaman guru terhadap pembelajaran berbasis budaya lokal masih memerlukan pembinaan serta pemahaman guru tentang materi kearifan lokal lampung berkaitan dengan prinsip hidup "Piil Pesenggiri" masih harus diberikan melalui pengembangan materi untuk memperluas pengetahuan guru sebelum melakukan kegiatan pembelajaran.

Keterlibatan sekolah, guru dan siswa pada kegiatan penelitian mencakup halhal berikut ini: (1) implementasi model pembelajaran; (2) refleksi pembelajaran pada refleksi terbatas; dan refleksi pembelajaran pada refleksi meluas. Penelitian ini baru menghasilkan draf materi pembelajaran tentang "PIIL PESENGGIRI" yang nantinya akan dijadikan sebagai modul atau bahan ajar dalam pembelajaran berbasis budaya lokal di SD Kota Metro. Selain itu berdasarkan hasil masukan dan pembahasan dalam kegiatan FGD bahwasanya dibutuhkan media pembelajaran berupa benner berdiri yang berikan tentang prinsip "PIIL PESENGGIRI" agar dapat dibaca oleh guru maupun siswa. Selanjutnya nanti juga akan dibuat rancangan pembelajaran dari 
RPP sampai dengan assesment pembelajaran terpadu berbasis budaya lokal Lampung.

\section{Rekomendasi}

Pembelajaran berbasis budaya lokal sangat diperlukan sebagai upaya untuk mempertahankan kebudayaan daerah masingmasing propinsi termasuk propinsi Lampung. Pada prinsipnya, Lampung memiliki falsafah hidup yang dikenal dengan lima aspek yaitu pi'il pesenggiri, bejuluk beadok, nemui nyimah, nengah nyampur dan sakai sembayan. Pi'il pesenggiri adalah rasa punya harga diri. Kemudian bejuluk-beadok (gelar adat) merupakan identitas utama yang melekat pada pribadi. Bejuluk-beadok merupakan asas identitas dan sebagai sumber motivasi bagi anggota masyarakat Lampung untuk dapat menempatkan hak dan kewajibannya, kata dan perbuatannya dalam setiap perilaku dan karyanya. Falsafah yang ketiga yaitu nemui-nyimah merupakan ungkapan asas kekeluargaan untuk menciptakan suatu sikap keakraban dan kerukunan serta silaturahmi. Bentuk konkrit nemui nyimah dalam konteks kehidupan masyarakat dewasa ini lebih tepat diterjemahkan sebagai sikap kepedulian sosial dan rasa setiakawan.

Suatu keluarga yang memiliki kepedulian terhadap nilai-nilai kemanusiaan, tentunya berpandangan luas ke depan dengan motivasi kerja keras, jujur dan tidak merugikan orang lain. Falsafah yang keempat yaitu nengah nyampur merupakan sikap suka bergaul suka bersahabat dan toleran antar sesama. Nengah-nyampur menggambarkan bahwa anggota masyarakat Lampung mengutamakan rasa kekeluargaan dan didukung dengan sikap suka bergaul dan bersahabat dengan siapa saja, tidak membedakan suku, agama, tingkatan, asal usul dan golongan. Falsafah yang terakhir yaitu sakai sembayan bermakna tolong menolong dan gotong royong, artinya memahami makna kebersamaan atau guyub.
Sakai-sambayan pada hakekatnya adalah menunjukkan rasa partisipasi serta solidaritas yang tinggi terhadap berbagai kegiatan pribadi dan sosial kemasyarakatan pada umumnya. Sebagai masyarakat Lampung akan merasa kurang terpandang bila ia tidak mampu berpartisipasi dalam suatu kegiatan kemasyarakatan. Perilaku ini menggambarkan sikap toleransi kebersamaan, sehingga seseorang akan memberikan apa saja secara suka rela apabila pemberian itu memiliki nilai manfaat bagi orang atau anggota masyarakat lain yang membutuhkan.

\section{Daftar Pustaka}

Alexon, Pembelajaran Terpadu Berbasis Budaya, Bengkulu: Unit FKIP UNIB Press, 2010.

Dokumentasi SD Muhammadiyah Tahun 2017.

Dominikus Tulasi, “Terpaan Media Massa dan Turbulensi Budaya Lokal" dalam Jurnal Humaniora Vol. 3 No. 1 April 202.

Eze, Ukamaka Teresa, Journal of Education and Practice www.iiste.org ISSN 22221735 (Paper) ISSN 2222-288X (Online) Vol.4, No.6, 201

George J. Sefa Die, Jurnal "Canadian and International Education", vol. 40 issue 1 tanggal 1 Juni 2011 Articles 3

http://kiens-edu.blogspot.co.id/2014/09/ pendidikan-berbasis-budaya-lokal. html diakses tanggal 28 Januari 2017

http://metromaju.blogspot.co.id/2012/10/datasd-di-kota-metro.html

http://www.jurnalguru.net/2016/11/ mendikbud-kota-metro-sebagai-kota. html diakses tanggal 03 April 2017

Journal of Education and Practice www.iiste. org ISSN 2222-1735 (Paper) ISSN 2222288X (Online) Vol.6, No.33, 2015.

Nirva Diana, "Manajemen Pendidikan Berbasis Budaya Lokal Lampung (Analisis Eksploratif Mencari Basis Filosofis)" 
dalam Jurnal Analisis Vol. XII, Nomor 1 Juni 2012.

Nita Fitria, “Bimbingan Kelompok Berbasis Tata Nilai Budaya Lampung Untuk Meningkatkan Tingkah Laku Prososial Siswa" dalam Jurnal Fokus Konseling, Vol. 1 No. 2 Agustus 2015.

Nita Fitria, "Pola Asuh Orang Tua Dalam Mendidik Anak Usia Pra Sekolah Ditinjau Dari Aspek Budaya Lampung", dalam Jurnal Fokus Konseling Volume 2 No. 2, Agustus 2016.

Olcott Jr. D., Carrera Farran, X., Gallardo Echenique, E. E., \& González Martínez, J. (2015). Ethics and Education in the Digital Age: Global Perspectives and Strategies for Local Transformation in Catalonia. RUSC. Universities and Knowledge Society Journal, 12(2). pp. 5972. doi http://dx.doi.org/10.7238/rusc. v12i2.2455

Pairin dan Djohan, Metro Sebagai Kota Pendidikan dan Wisata Keluarga, visi misi yang disampaikan tanggal 29 Juli 2015.

Phaedra Mohammed and Permanand Mohan, Caribbean Teaching Scholar Vol. 1, No. 1, April 2011, 21-33

Proceedings of The 4th International Conference on Teacher Education; Join Conference UPI \& UPSIBandung, Indonesia, 8-10 November 2010

Sugiono. Metode Penelitian Kuantitatif Kualitatif dan RED. Bandung, Alfabeta, 2012.

Sutrisno Hadi, Metodologi Research II, Yogyakarta, Fakultas UGM, 2004.

Tatang M. Amirin, “ Implementasi Pendekatan Pendidikan Multikultural Kontektual Berbasis Kearifan Lokal Di Indonesia" dalam Jurnal Pembangunan Pendidikan Fondasi dan Aplikasi. Fakultas Ilmu Pendidikan Universitas Negeri Yogyakarta. Vol. I, Nomor I Juni 2012.

Team Penyusun, Pedoman Penulisan Skripsi
Karya Ilmiah, Ed. Revisi, STAIN Jurai Siwo Metro, 2010.

Udin S. Winataputra, Pembaharuan Pembelajaran IPS di SD. Jakarta: Universitas Terbuka, 2012.

Umar M. Sadim, dkk., "Revitaisasi Nilai-Nilai Bhinneka Tunggal Ika dan Kearifan Lokal Berbasis Leaning Society Pascakonflik Sosial di Ternate" dalam Jurnal Pembangunan Pendidikan: Fondasi dan Aplikasi P-ISSN: 2356-1807 e-ISSN: 2502-1648

UU No. 14 Tahun 2005 tentang Guru dan Dosen BAB IV Pasal 8 dan 10"Kualifikasi, Kompetensi dan Sertifikasi"

Wahira, "Kebutuhan Pelatihan Manajemen Pembelajaran Seni Tari Berbasis Pendekatan Saintifik Pada Guru Sekolah Dasar" dalam Catharsis: Journal of Arts Education 3 (2) 2014.

Widhiya Ninsiana, "Pendekatan Multikultural dan Kearifan Lokal: Solusi Dalam Masalah Konflik Lampung" dalam Jurnal Akdemika, Vol XVII, No. 1 januari-Juni 2012.

Zudan Rosyidi, "Perspektif Budaya Lokal Dalam Pembelajaran Di Sekolah Tingkat Dasar" dalam MADRASATUNA (Jurnal Pengembangan MI Volume 03, Nomor 02 Maret 2012) 
72| Blementinly Vol. 6 No. 1, January-June 2020

This page intentionally left blank 